\title{
Crohn's disease with pulmonary involvement in a 3 year old boy
}

\author{
C J Calder, D Lacy, F Raafat, P H Weller, I W Booth
}

\begin{abstract}
Extra-intestinal or metastatic Crohn's disease is being recognised increasingly, most commonly in the skin and genitourinary system. Only very rarely has it been reported in the lung. A 3 year old boy who presented with swollen gums and a persistent abnormality on his chest $x$ ray is reported. Lung biopsy specimens showed multiple non-caseating epithelioid granulomas. Subsequent investigation showed the presence of intestinal Crohn's disease. The evidence for abnormal lung function in Crohn's disease and the possible pathogenesis of metastatic pulmonary Crohn's disease are discussed.

(Gut 1993; 34: 1636-1638)
\end{abstract}

Latent pulmonary abnormalities, disclosed by pulmonary function tests and bronchoalveolar lavage, have been found in patients with Crohn's disease. ${ }^{1-3}$ However, the finding of non-caseating granulomas in these patients is very rare. ${ }^{48} \mathrm{We}$ report a further case of extra-intestinal Crohn's disease affecting the lung, which occurred in a child who had radiological abnormalities on chest $x$ ray at presentation.

\section{Case history}

A 3 year old boy presented to his dentist with swollen red gums which bled on brushing. His only other symptom was perianal soreness and occasional bleeding. His father was Indian and his mother white European. He had two elder siblings who were both well. There was no family history of tuberculosis or inflammatory bowel disease. He had never been abroad.

\section{INVESTIGATIONS}

Chest $x$ ray showed densities in the right middle and the lower lobes of the lung (Fig 1). There was no hilar lymphadenopathy. A small bowel enema examination was normal.

Other investigations showed mild anaemia (haemoglobin concentration $10.8 \mathrm{~g} / \mathrm{dl}$ ) with a raised erythrocyte sedimentation rate $(38 \mathrm{~mm}$ in the first hour). Serum immunoglobulin values were raised - IgG $21 \cdot 8 \mathrm{~g} / 1$ (normal 3.70-15.80 $\mathrm{g} / \mathrm{l}$ ) and $\operatorname{IgA} 2.07 \mathrm{~g} / \mathrm{l}$ (normal $0 \cdot 3-1 \cdot 3 \mathrm{~g} / \mathrm{l}$ ). The serum angiotensin converting enzyme activity was not raised. Repeated microbiological examination of sputum, blood, and urine proved negative. Mantoux testing $1 / 1000$ was negative.

Bronchoscopy failed to show an endobronchial lesion. Upper gastrointestinal endoscopy and colonoscopy were macroscopically normal and mucosal biopsy specimens were obtained. The anal skin tag and gums were biopsied and a thoracotomy and lung biopsies were performed. Lung tissue from the right middle and lower lobes was stained for acid and alcohol-fast bacilli but none were seen, and subsequent culture for Mycobacteria was negative. A Kveim test was negative.

\section{PATHOLOGICAL FINDINGS}

Granulomatous inflammation was present in the buccal mucosa, right middle and lower lobes of the lung (Fig 2), and the anal skin tag. The granulomas had a similar structure at all these sites, and were non-caseating and epethelioid. Many were surrounded by a thin mantle of small lymphocytes. Multinucleated giant cells of the Langhan's type were present in the granulomas. In the lungs, the granulomas were both peribronchial and perivascular in distribution. In all of these biopsy specimens special stains for organisms (fungi, acid and alcohol-fast bacilli, etc) were negative.

Specimens taken at various levels in the colon showed a microscopic colitis that was maximal in the transverse colon. This was characterised by moderate active chronic inflammation in the lamina propria. There were incipient but not established crypt abscesses. The architecture of the gland crypts was well preserved and there was mild goblet cell mucous depletion. No granulomas were present.

\section{Discussion}

Our patient had Crohn's disease: the macroscopic and histological features of the oral and

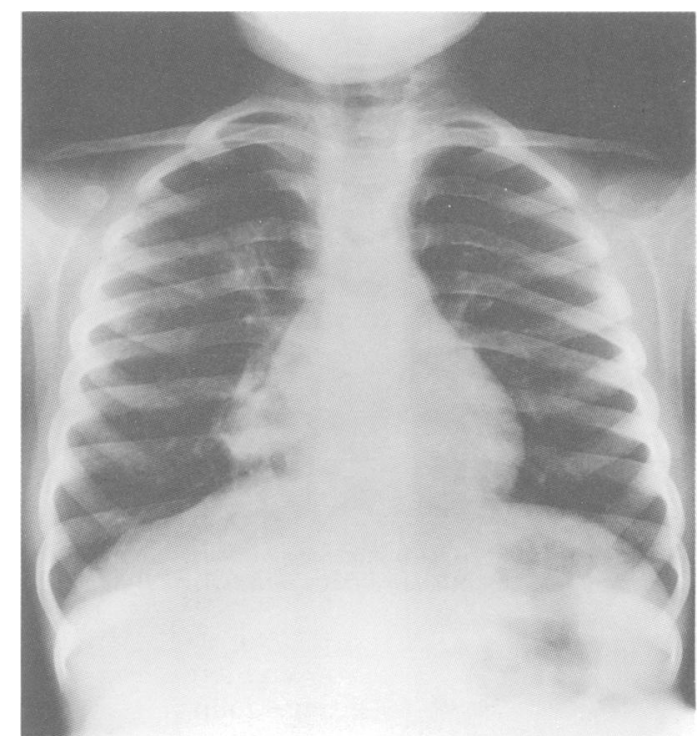

Figure 1: Chest $\mathrm{x}$ ray showing densities in the right middle and lower lobes. 


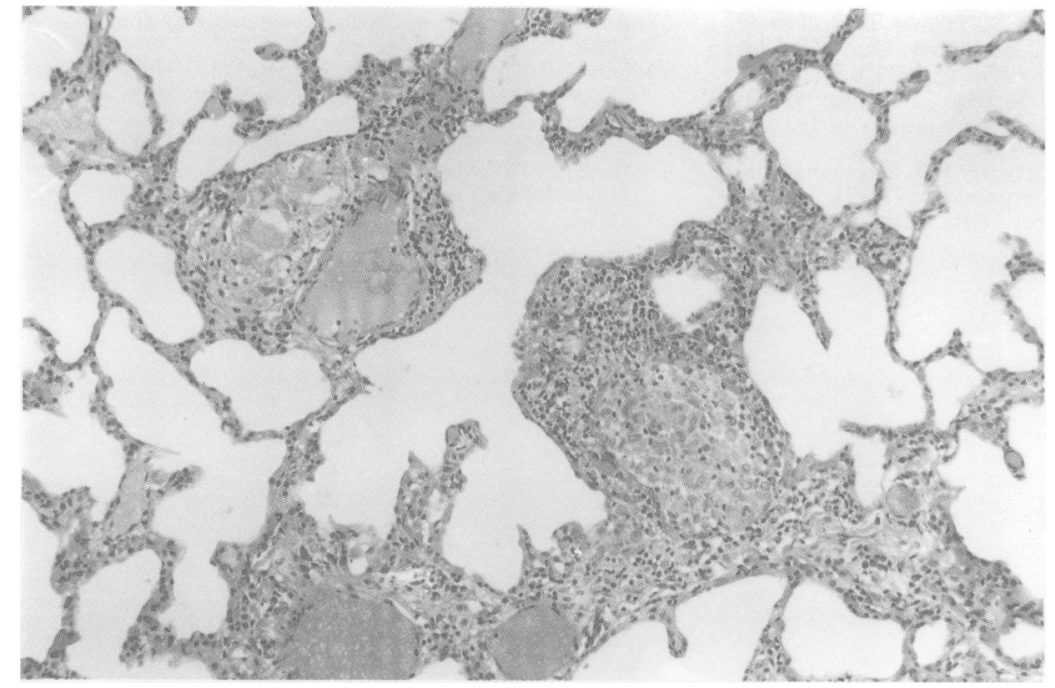

Figure 2: Right middle lobe of lung showing two non-caseating epithelioid granulomas, haematoxylin and eosin $\times 100$.

perianal lesions are typical. He also had a microscopic colitis consistent with Crohn's disease, although no granulomas were seen.

Extra-intestinal involvement in Crohn's disease has been reported increasingly and has been described in the skin, ${ }^{49}$ vulva, ${ }^{10-13}$ bone, ${ }^{14}$ and lung. ${ }^{+8}$ In all these organs extra-intestinal Crohn's disease is characterised by nonnecrotising epithelioid granulomas. It therefore seems that Crohn's disease should be regarded as a multisystem disorder that affects maximally the gastrointestinal tract. Pulmonary involvement has been recognised before ${ }^{4}$ after, ${ }^{8}$ and concurrently (as in our case) with the onset of bowel disease. The course and severity of the pulmonary involvement does not seem to be related to the activity of the intestinal disease.

Pulmonary involvement in Crohn's disease is rare, although some studies suggest that patients with Crohn's disease may have abnormal lung function in the absence of symptoms. ${ }^{1-3}$ Both Bonniere $e t a l^{2}$ and Heatley $e t a l^{3}$ have shown impaired carbon monoxide transfer factors in 25 to $40 \%$ of adult patients with Crohn's disease. Heatley et al also found radiographic abnormalities in some of these patients that were indistinguishable from those seen in pulmonary fibrosis. The latter is a heterogenous group of disorders that represent the end stage of a variety of disease processes, some of which can be associated with non-caseating granulomas in the lung. ${ }^{15}$ Bronchoalveolar lavage has yielded alveolar lymphocytosis in up to $54 \%$ of patients with Crohn's disease and this seems to be a persistant abnormality. ${ }^{2}$ Alveolar lymphocytosis is a well recognised feature of other pulmonary granulomatous processes such as sarcoidosis. Furthermore, in both Crohn's disease and sarcoidosis the lymphocytosis seems to arise from an expansion of the T4 subset.

Sarcoidosis with intestinal involvement is the main differential diagnosis in our patient. Sarcoidosis is very rare in children and intestinal sarcoidosis is extremely rare being reported only when there is active disseminated disease. ${ }^{16-18} \mathrm{We}$ have found no recorded case where intestinal sarcoidosis has been manifest as an anal skin tag associated with a microscopic colitis. The serum angiotensin converting enzyme activity was not raised in our patient, and several groups have reported high values in sarcoidosis but low values in Crohn's disease. ${ }^{219}$ The Kveim test was negative.

There are similarities between sarcoidosis and Crohn's disease; both are conditions of unknown aetiology characterised by non-caseating epithelioid granulomas and a tendency for fibrosis. There are also similarities in the complications seen in the two diseases such as erythema nodosum, uveitis, and arthritis. It therefore seems likely that the two conditions are not as distinct from each other as was once thought. There are families in whom the two conditions coexist $^{20}$ raising the possibility that they share a similar genetic predisposition and possibly a common transmissable agent such as a mycobacterium.

There are similarities between the local immune system in the gut and the lung. Both of these organs have mucosa associated lymphoid tissue (MALT), which, in the lung, is referred to as bronchial associated lymphoid tissue (BALT). In animal studies of MALT, ${ }^{21} \mathrm{~B}$ cells activated by antigenic challenge migrate via the efferent lymphatic vessels. These cells then 'home' back to the mucosa from which they originated. There is also some evidence for a homing population of mucosa associated $\mathrm{T}$ cells, ${ }^{21}$ and consequent interaction between humoral and cell mediated immunity with secretion of cytokines. This suggests that there could be a common antigenic stimulus resulting in the pulmonary and intestinal manifestations of both Crohn's disease and sarcoidosis. The site of the original interaction between antigen and the immune system presumably determines the distribution of the granulomatous inflammation seen.

1 Eade OE, Smith CL, Alexander JL, Whorwell PJ. Pulmonary function in patients with inflammatory bowel disease. Am F Gastroenterol 1980; 73: 154-6.

2 Bonniere P, Wallaert B, Cortot A, Marchandise X, Riou Y, Tonnel AB, et al. Latent pulmonary involvement in Crohn's disease: biological, functional, bronchoalveolar lavage and scintigraphic studies. Gut 1986; 27: 919-25.

3 Heatley RV, Thomas P, Prokipchuk EJ, Gauldie J, Sieniewicz DJ, Bienenstock J. Pulmonary function abnormalities in patients with inflammatory bowel disease. $Q \mathcal{F}$ Med 1982 203: 241-50.

4 Henrion F, Bretagne MC, Neimann L, Flechon PE, Canton P, Hoeffel JC. Association exceptionnelle de lesions pulmonaires, cutanées et d'une ileite terminale chez une pulmonaires, cutanes et d'une ileite termin

5 Shah SM, Texter EC, White HJ. Inflammatory bowel disease associated with granulomatous lung disease: report of a case with endoscopic findings. Gastrointest Endosc 1976; 23 :

6 Lehmann M, Messing B, D'Agay F, Modigliani R. Crohn's disease with respiratory tract involvement. Gut 1987; 28 1669-72.

7 Puntis JWL, Tarlow MJ, Raafat F, Booth IW. Crohn's disease of the lung. Arch Dis Child 1990; 65: 1270-1.

8 Kayser K, Probst F, Gabius HJ, Muller KM. Are there characteristic alterations of lung tissue associated with Crohn's disease? Path Res Pract 1990; 186: 485-90.

9 Puntis JWL, Candy DCA, Alexander-Williams J, Kelsey A Widespread cutaneous Crohn's disease presenting in child

10 Lally MR, Orenstein SR, Cohen BA. Crohn's disease of the vulva in an 8 year old girl. Pediatr Dermatol 1988; 5: 103-6.

11 Lavery HA, Pinerton JHM, Sloan J. Crohn's disease of the vulva. Brf Dermatol 1985; 113: 359-63.

12 Schulman D, Beck LS, Roberts IM, Schwartz AM. Crohn's disease of the vulva. Am $\mathcal{F}$ Gastroenterol 1987; 82: 1328-30.

13 Pokorny SF. Prepubertal vulvovaginopathies. Obstet Gynecol Clin North Am 1992; 19: 39-59.

14 Bookman AA, Gould MI, Barrowman JA, Chittal SM Periosteal new bone formation and disseminated granulomatosis in a patient with Crohn's disease. Am J Med 1988; 84: $330-3$

15 Dunnill MS. Pulmonary fibrosis. Histopathology 1990; 16: 
16 Sprague R, Harper P, McClain S, Trainer T, Beeken W. Disseminated gastrointestinal sarcoidosis. Case report an review of the literature. Gastroenterology 1984; 87: 421-5.

17 Gould SR, Handley AJ, Bernado DE. Rectal and gastric involvement in a case of sarcoidosis. Gut 1973; 14: 971-3.

18 Konda J, Ruth M, Sassaris M, Hunter FM. Sarcoidosis of the stomach and rectum. Am 7 Gastroenterol 1980; 73: 516-8.

19 Nunez-Gornez JF, Tweksbury DR. Serum angiotensin convering enzyme in Crohn's disease. Am $\mathcal{F}$ Gastroenterol 1981; 75: 384-5.

20 Bambery P, Kaur U, Bhusnurmath SR, Dilawari JB. Familial idiopathic granulomatosis: sarcoidosis and Crohn's disease in two Indian families. Thorax 1991; 46: 919-21.

21 Isaacson PG, Wright DH. Extranodal lymphoma. In: Anthony PP, MacSween RNM, eds. Recent advances in histopathology, 13. Edinburgh: Churchill Livingstone, 1987: $160-2$. 